\title{
"I Wish to be Free of All Things I Am Not and Will Never Be": Reorientation of Self Through the (re)Framing of (post)Colonial Consciousness in Marie Clements' The Edward Curtis Project.
}

\author{
Ahmed P. Alkubaisy
}

[Act One: Prelude.] As the audience bursts into the "sound of thunderous applause," Edward Curtis steps into view as the "rich backdrop of Carnegie Hall fades up: dark-gold and auburn Greek pillars and grandeur" (Clements 453). Moments before he starts his lecture in New York, 1911, Curtis “poses, adjusting his face in the light for effect” (Clements 454), providing his audience, viewers, and readers, both in person and textually, with a picture, a portrayal, and a frame for others' gaze to filter through - the perfect image of a scholar, an ethnographer, and an explorer, who, much like his minute attention to lighting, attempts to shed light upon the issues of his world. Who is this noble figure, then? Here's a picture: Edward Sheriff Curtis, born in Wisconsin, married at the age of twenty-two, had four children, ethnologist and photographer by trade, an Aquarius by sign, and his cause of death: a long-term ailment. Whether this description of Curtis is an accurate portrayal is up for debate, since pictures are hand-crafted objects, much like texts, which can (and do) provide and withhold certain information. Indeed, the readers who are unaccustomed to Curtis and his work, may not be able to differentiate between the "truth" and "lies." "[P]hotographs alter and enlarge our notions of what is worth looking at and what we have a right to observe. They are a grammar and, even more importantly, an ethics of seeing" (Sontag 1).

As an ethnologist and photographer, Edward Curtis is a "weighty historical figure... who took over 20,000 photographs [which] have been, for over one hundred years, the international community's main point of access to representations of aboriginal peoples" (Nanibush). In his multi-volume 1907 book, The North American Indian, Curtis attempts to document through still images and other media more than 80 American Indian tribes, their traditions, and customs. His work has significantly influenced the public's perceptions of 
Indigenous cultures, "yet it is a work that, in attempting to capture the image of authentic, pre-contact Aboriginal culture, problematizes the limits of representation, where truth becomes merely a perspective" (Nanibush). [Light fades, leaving Curtis in shadow while a new figure is illuminated.] In contrast stands Marie Humber Clements, a playwright, director, and performer of Canadian Métis descent, whose play, The Edward Curtis Project, presents a different perspective of the life of the famous photographer. Enlisting the help of photographer Rita Leistner, Clements conceives a twofold approach, one that is textual and another that is visual; the former provides the context for the latter, and vice-versa, for the two works command a bidirectional relationship that work in tandem with each other. In order to understand these different perspectives, or orientations, both Edward Curtis and Marie Clements are analyzed in an attempt to (re)frame and problematize discourses regarding (re)presentation, (post)colonial consciousness, and Subject/Object dynamics.

[Act Two: Discourse, Dialectics, (De)colonization.] During the first several decades of the twentieth century "institutionalized anthropology in North America was predominantly defined by the ideology and practice of 'salvage ethnography." As cultural studies professor Pauline Wakeham notes, "According to the logic of the salvage paradigm, Native cultures hovered on the brink of extinction, destined to collapse under the inevitable tide of western progress" (Wakeham 294). In addition, this ethnographic practice shares linguistic roots with the word "salvation," a concept fulfilled only by a savior - in this case, the white savior complex; this complex rises from a colonial system of thought that separates the Self from the Other, and views the latter as peripheral, non-essential, regressive, and therefore in need of help from the profressive Self. Measured against western progress, the Other's "inability" to "advance" quickly enough causes cultures to dissolve and vanish, or so suggests salvage ethnography. Therefore, the "Other" worlds encountered by travelers "were interpreted by them through ideological filters, or ways of seeing, provided by their own cultures and societies" (Loomba 64). This savior complex was one of the forces driving Curtis' work, and he sought it by looking for authenticity, the original "Vanishing Indian."

Edward Curtis' fascination with The Vanishing Indian ignores the implications of colonial contact and erases traces of western influence, which are essential to the progression of Aboriginal identity and culture. In her study, Colonial Photography and Exhibitions: Representations of the 'Native' and the Making of European Identities, Anne 
Maxwell suggests that, aside from being a function of assigning value, "[ $t]$ he nineteenthcentury anthropologists' obsession with authenticity was also ... a function of the ability to camouflage the damage inflicted by colonialism." Curtis, she argues, "was prepared to go to great lengths to produce images that showed no trace of western influence" (qtd. in Nanibush). His obsession with authenticity led him to package the "national tragedy" of a "vanishing race" in a compendium - a history that can be read (qtd. in Wakeham 297). This packaging was produced through the art of photography, which is a tool used to freeze a moment or to freeze a reality - "that picture-taking services a high[er] purpose: uncovering a hidden truth, conserving a vanishing past" (Sontag 43 emphasis mine). As Susan Sontag suggests in On Photography, "[t]o photograph people is to violate them, by seeing them as they never see themselves, by having knowledge of them they can never have; it turns people into objects that can be symbolically possessed" (10). The work of Edward Curtis implements this symbolic possession, this "sublimated murder - a soft murder" (Sontag 10). Colonial contact is not just reflected in the imagery of the works, but is a central aspect of what these works say about identity and culture. This enactment of the binary in Curtis' visual representations is "as [Edward] Said's Orientalism suggested, a part of the creation of colonial authority" (Loomba 66), which resulted in the salvage ethnography's expansion from recording artifacts to the production of artifacts - a fetishistic process whereby the imagined lost object of primitive origins was replaced with the west's own reconstruction of "a pre-contact Native state of nature" (Wakeham 294).

Edward Curtis' production of the photographic artifact created a commodity that contains and frames a colonial consciousness. As [author] notes, "[i]t is not consciousness of men that determines their being, but on the contrary, their social being that determines their consciousness" (qtd. in Fromm 18). Since Curtis' photographs do not exist in a vacuum, and are informed by various cultural and political discourses, they carry a symbolic meaning and confer power and value: “[m]en are the producers of their conceptions, ideas, etc..." (Fromm 18). Karl Marx believed that most of what individuals think is "false" consciousness, marred in ideology and rationalization. According to Marxist theory, “the blindness of man's conscious thought... prevents him from being aware of his true human needs, and of ideals which are rooted in them" (Fromm 19). Then, only if false consciousness is transformed into true consciousness, "that is, only if we are aware of 
reality rather than distorting it by rationalizations and fiction, can we also become aware of our real and true human needs" (Fromm 19). Moreover, for Marx, an object is always in its movements, in its becoming, and not as a static object, but rather as an object in flux between the Subject and Object dichotomy (Fromm 10). Subject and Object cannot be separated. It is therefore in false consciousness that Subject distances itself from Object, or, in other words, it is through colonial consciousness that the Self separates from Other.

[Act Three: Explication, Exploration, Application.] When the Subject and Object dichotomy are isolated from each other, a hierarchy arises that places the former above the latter, creating a power dynamic that provides the authority for dominance. In order to understand these dynamics, I use a three-pronged, broad-to-narrow approach to explicate Marie Clements' play, The Edward Curtis Project. First, the focus will be on the audience as a part of the (re)orientation process; second, I move towards the stage, actors, and general narrative; and third, I will highlight the frames, both of consciousness and its physical manifestation, to explore the theoretical implications of the drama, and the spaces in which these paradigms are enacted. Clements' play is partially based on the tragic freezing deaths of two young girls in January 2008 on Saskatchewan's Yellow Quill Reserve: in the middle of the night during a snowstorm, Christopher Pauchay left his home while under the influence of alcohol with his two daughters, 15-month-old Santana and 3-year-old Kaydance. He was found at 5 a.m. and taken to the hospital; the children were found dead after an extensive two-day search. This story sets the main trajectory for the play, which details journalist Angeline's struggle with representing the "truth" of this tragedy as she plunges inwardly into her own consciousness, into the liminal space of her thought, where she must search and free herself from the colonial frame.

A theatre, filled to capacity, contains a multiplicity of people with varying levels of awareness and experience; as people enter into a theatre for a viewing, they arrive with their own ideological lens through which they view the performance. These lenses are varying, established by the numerous experiences, which, over time, shape and mold consciousness. Therefore, when an audience encounters a play attempting to convey its own truth(s), the viewers have already established a pre-conception of these truths. One of the dramatist's goals is to reorient the audience's understanding, or consciousness, in order to raise an awareness of a new perspective. Indeed, much like the play itself, in which 
Angeline attempts to deal with her crisis and her reorientation, the audience too, whether consciously or subconsciously, is internalizing these messages, and negotiating their own reorientation. [Act Four: The Textual.] Within the first act of Clements' play, readers and viewers discover the initial framing of Angeline's viewing, in a literal sense, for as Angeline "wakes from a deep sleep[,] [f]amily photographs begin to develop on the dark walls surrounding her" (451). These family photographs exist not only for Angeline to interact with, but also with the audience; this double image creates a surrealist experience that drives the audience to suspend their disbelief further. Sontag argues that "Surrealism lies at the heart of the photographic enterprise: in the very creation of a duplicate world, of a reality in the second degree, narrower by more dramatic than the one perceived by natural vision" (40). Arguably, then, surrealism's enabling of the suspension of disbelief aids in the reorientation of consciousness, since the audience is more willing to accept other notions opposing what they believe is reality.

Through the suspension of disbelief, Angeline tampers with the narrative already established by the family portraits. "We posed like all families pose," she said, "[a]rranging ourselves... until we began to understand with age... our poses had always been prearranged" (Clements 451). Much like the audiences pre-understandings, Angeline, using a collective "we," begins to understand that her family has been frozen, in a specific state that was "pre-arranged." These family moments are rendered into Objects, devoid of any intrinsic meaning but that implied by the photographer and viewer(s). Angeline then begins to caption these images, inscribing them with keywords such as "mother," "father," and "daughter of mixed marriage" (Clements 451); these inscriptions subvert the objectification of the photograph with Angeline's own textual subjectivity. When it is her turn to label herself, she refers back to a caption "in the darkness [she] can identify with... The Vanishing Indian" (Clements 453). Thus, Angeline uses the colonizers inscription in order to assert her own value, colonizing her own consciousness as she finds a darkness to cling to while rending herself into an Object. However, "Angeline's hybridity as a person of Dene and Russian heritage is also enacted by this duality - she is both subject and object." (Couture 15).

Even though Angeline ascribes to the image of the Vanishing Indian, when faced with her colonizer Edward Curtis who suggests that he is going to call her a "Primitive 
Indian Wo[man]" (Clements 455), she begins to question the subjectivity that he attempts to impose on her: "Aren't you going to ask me what I call myself" (Clements 455). Then, Angeline "takes his journal and pen and crosses out the 'Primitive Indian Wo[man,] ... and writes 'Most Beautiful Women You've Ever Met'” (Clements 455). Angeline is in a constant struggle, having to negotiate her representation and mediate it between the colonizer's subjectivity and her own. By resisting Curtis' domination through his entrapment of her with his colonial frames, she successfully dislodges the Self/Other and Subject/Object binaries, asserting her Self/Subjectivity by reorienting and appropriating the power of language, pushing her perceived Otherness/Objectification away.

Indeed, it is not only Angeline that Curtis attempts to render into object, but her ancestry as a whole in the "far away enchanted realm of primitive man" (Clements 454). For example, Edward Curtis passionately states: "I wrote about it... the Sun Dance... I was the first white man to write about it. To take a picture so no one would forget they were here" (Clements 458). The photographer, according to Wakeham, attempts to "capitalize upon white mythologies of primal otherness[.] Curtis constructed a... narrative that played to sensationalistic colonial stereotypes of savage 'rituals' such as scalping, decapitation, and sorcery, packing it all as a trip back in time" (298). Further, Curtis suggests that they thanked him for taking the picture, "for preserving it forever... because pictures are... realities" (Clements 458). Through his colonial lens Curtis is convinced that there was an implicit thankfulness towards his work, but what he fails to notice is that ideologically his endeavor is embedded within the savior complex, which implicitly requires the Other to blindly accept their salvation and return thanks for being saved by the white hero. This complex is made more visible in Angeline's response(s): “Did they... Did they really [thank you]?" and "Are they [realities]? Or are they just perceptions?" (Clements 458). Moreover, other characters, such as Yiska, Angeline's boyfriend, rejects the colonial lens through which he is being peered: "We all look the same... don't worry about it" and "Listen... I don't like waking up to strange men... on my own land... especially those who talk too much and get things from my fridge" (Clements 461-62). By mocking the colonial gaze of homogeneity, and by making an implicit comment regarding exploitation of land and resource, through the use of the fridge as metaphor, Yiska challenges Curtis' (re)presentation of Aboriginal peoples. Both Angeline and her boyfriend's fight against 
colonial framing reaffirms Marx's concept regarding individuals carving their own realities, suggesting that one can carve colonial consciousness by unlearning it and setting oneself free from false consciousness.

[Act Five: The Visual.] The performance of The Edward Curtis Project included an installation by photojournalist Rita Leistner in a gallery attached to the theatre. Travelling with Marie Clements to Aboriginal communities throughout Canada and the United States, Leistner's work was a direct statement opposing the work of Edward Curtis who practiced the posing of his "subjects" with traditional regalia in an attempt at authenticity. This removal of any sign of contact obscured the effects of colonization, suggesting that " $[t]$ he Nobility of the 'Indian' and the tragedy of the passing of 'Indians' were intrinsically aesthetic and scientific 'subjects' (read as objects)" for Curtis (Nanibush). Unlike Curtis, Leistner allowed the Subjects to frame themselves; as Leistner explains in her artistic statement distributed at the gallery, "The diptych series [...] became a central scheme of the Edward Curtis Project - an exploration of past and present, traditional and modern, as presented by the subjects themselves" (qtd. in Couture 14). Much like Angeline's re-writing of the captions, Leistner attempts to convey images of Aboriginal peoples that are inscribed with their Subjectivity as participating agents of the image. From passive Object to active Subject, Leistner manifests Angeline's textual subversion into physical reality.

In many of Leistner's images, the dualities of Self/Other and Subject/Object are destabilized and transformed. Appropriately the photojournalist opted for diptychs, a duality in itself, which portray in the first image Aboriginal people posed in modern clothing, and in the second image the same pose is held, but traditional clothing is used. These diptychs are an artistic affirmation of the surviving and vibrant people Curtis had framed as 'vanishing,' a direct challenge to the "monovalent single images that effectively erased the present in favour of romantically celebrating the past" (Couture 14). These visuals enable a subjectivity otherwise partially missing from Clements' play. "[M]ost people don't want to hear the whole truth... they don't want to see it, they just want us to disappear," suggests Yiska (Clements 465). The "whole truth" surfaces in the diptychs, then. Leistner's photographs and Clements's play are connected through the recognition that photographic documentation is seductive in its apparent truth-telling, but that it is always a process of choosing what to include in the frame and what to exclude from it. "By 
presenting the photo installation and theatrical performance at the same time - one working in Curtis' medium but consciously foregrounding the framing of a subject and the other bringing a subject to life to interact with Curtis - the audience is given access to multiple points of view and possible truths" (Couture 14).

[Act Seven: Epilogue.] Edward Curtis' seminal work, The North American Indian locates Aboriginal People firmly in the past, within a colonial gaze that views them as vanishing. Through this positioning Curtis maintains his Self, separates it from his "Subjects" by photographing them, freezing them, much like the children in Clements Drama, and thus rendering them as Objects/Others to be oriented at his own will. However, through Marie Clements' The Edward Curtis Project, and subsequently through Rita Leistner's accompanying photographic exhibit, Aboriginal subjectivity is affirmed, a new truthful (re)presentation comes to light, and the Other is transformed into the location of Self. Since "academic recovery has created a mythology [around Curtis] ... that treads the fetishizing of Curtis' text as a lost and recovered (and supposedly authentic) fragment of North American cultural memory" (Wakehead 295), Clements work thwarts colonial framing and (re)orients viewers and readers alike away from false colonial consciousness. 
Works Cited

Clements, Marie. "The Edward Curtis Project." Modern Canadian Plays. By Jerry Wasserman. 5th ed. Vol. 2. Vancouver: Talon, 2013. 449-73. Print.

Couture, Selena. "Frames Of Mind: Beyond Eden And The Edward Curtis Project." Alt.Theatre: Cultural Diversity and The Stage 8.2 (2010): 10-17. MLA International Bibliography. Web. 5 Dec. 2015.

Fromm, Erich, and Karl Marx. Marx's Concept of Man. New York: F. Ungar, 1966. Print.

Loomba, Ania. Colonialism/postcolonialism. London: Routledge, 2005. Print.

Nanibush, Wanda. "The Frozen Bodies of Edward S. Curtis." Reviewcanada.ca. Literary Review of Canada. Web. 02 Dec. 2015.

Sontag, Susan. On Photography. New York: Farrar, Straus and Giroux, 1977. Print.

Wakeham, Pauline. "Becoming Documentary: Edward Curtis's In The Land Of The Headhunters And The Politics Of Archival Reconstruction." Canadian Review of American Studies/Revue Canadienne D'etudes Américaines 36.3 (2006): 293-309. MLA International Bibliography. Web. 5 Dec. 2015. 